\title{
Bony swellings: an enigma
}

\author{
Vikram Singh Shekhawat, Anil Bhansali
}

Department of Endocrinology, Postgraduate Institute of Medical Education and Research, Chandigarh, India

\section{Correspondence to} Dr Vikram Singh Shekhawat, anilbhansaliendocrine@gmail. com and Dr Anil Bhansali, anilbhansaliendocrine@gm ail.com

Accepted 8 January 2018

\section{DESCRIPTION}

A 57-year-old female presented with history of rapidly progressing multiple swellings over her face, forehead and sternum for the last 6 months (figure 1). On examination, these swellings were non-tender and hard in consistency. Her thyroid gland was not palpable. Thyroid function tests were normal. FNAC (Fine needle aspiration cytology) from the bony swelling revealed metastatic follicular thyroid carcinoma (FTC) (figure 2) with thyroglobulin (Tg) positivity on immunohistochemistry. Ultrasonography of the neck revealed a normal-sized thyroid gland with multiple hypoechoeic lesions and calcification. FDG-PET (Fluorodeoxyglucose - positron emission tomography) displayed diffuse osseous metastasis. She underwent total thyroidectomy, and histopathology was consistent with FTC. Postoperatively, serum Tg was $552 \mathrm{ng} / \mathrm{mL}$ (normal 1.4-78 ng/mL) and anti-Tg antibody was $15 \mathrm{IU} / \mathrm{mL}$ (normal <60 IU/mL). She also received zoledronic acid and high dose radioiodine ablation with scan showing a faint tracer uptake by the metastatic lesions. The patient was lost to follow-up and died a year after she presented first.

Malignancies associated with a tendency to metastasize to flat bones include thyroid, breast and prostate carcinoma. Thyroid malignancy is rare and accounts for only $2 \%$ of all solid malignancies. FTC occurs in older people, the mean age at diagnosis being 50 years. Painless thyroid nodule is the most common presenting manifestation, while 1\%-9\% present with distant metastasis, as seen in our patient. The lung $(50 \%)$ and bone $(25 \%)$ are the most common sites of distant metastasis and bony lesions are mostly osteolytic. ${ }^{1}$ More than $80 \%$ of bone metastases from thyroid malignancies are located in the red marrow of the axial skeleton, where blood flow is high (eg, vertebrae, ribs and hips) and a conducive milieu exists for

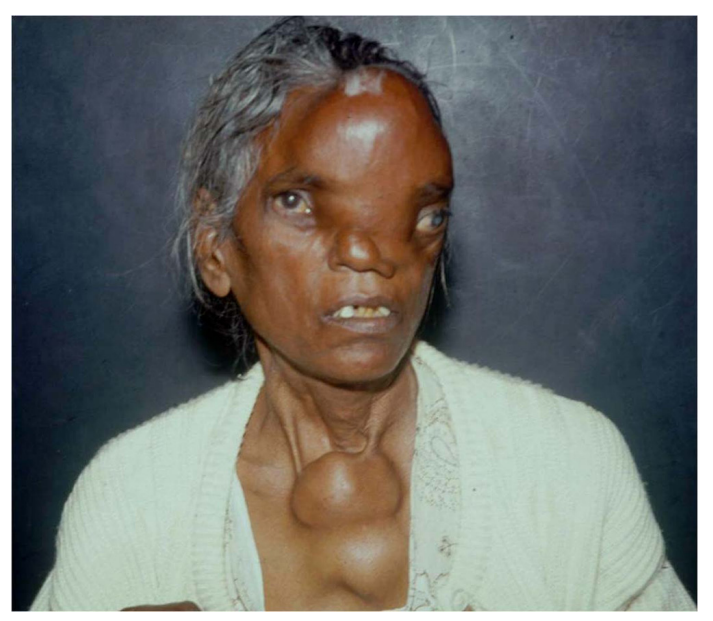

Figure 1 Clinical photograph of the patient showing multiple bony swellings over forehead, face and sternum.

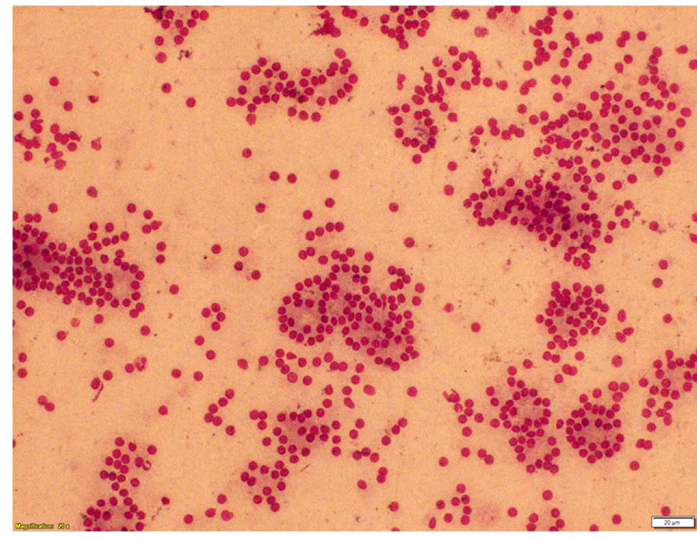

Figure 2 FNAC (Fine needle aspiration cytology) of the bony swelling showing abundant cellularity with cells showing predominantly follicular pattern.

tumour growth due to the presence of growth factors, such as IGF-1 (Insulin-like growth factor-1) and IGF-2 (Insulin-like growth factor-2, FGFs (Fibroblast growth factors) and PDGFs (Platelet derived growth factors). ${ }^{2}$ Thyroid carcinoma with distant metastasis is associated with poor prognosis with 10 -year survival rate of $40 \% .^{3}$

\section{Learning points}

Follicular thyroid carcinoma presenting with bony metastasis is quite uncommon.

- Presence of bony metastasis in FTC is associated with poor prognosis.

- Majority of the bony metastasis in FTC involve vertebrae, ribs and pelvic bones; however, skull involvement is not very frequent.

- Lenvatinib, an oral multitargeted tyrosine kinase inhibitor, is an effective therapeutic alternative in radioiodine refractory metastases.

Contributors VSS prepared and edited the manuscript. $A B$ diagnosed and managed the case and also edited the manuscript.

Funding This research received no specific grant from any funding agency in the public, commercial or not-for-profit sectors.

Competing interests None declared.

Patient consent Obtained.

Provenance and peer review Not commissioned; externally peer reviewed.

(C) BMJ Publishing Group Ltd (unless otherwise stated in the text of the article) 2018. All rights reserved. No commercial use is permitted unless otherwise expressly granted.

\section{REFERENCES}

1 Shaha AR, Shah JP, Loree TR. Differentiated thyroid cancer presenting initially with distant metastasis. Am J Surg 1997;174:474-6.

2 Muresan MM, Olivier P, Leclère J, et al. Bone metastases from differentiated thyroid carcinoma. Endocr Relat Cancer 2008;15:37-49. 


\section{Images in...}

3 Haugen BR, Alexander EK, Bible KC, et al. 2015 American Thyroid Association Management Guidelines for Adult Patients with Thyroid Nodules and Differentiated

Thyroid Cancer: The American Thyroid Association Guidelines Task Force on Thyroid Nodules and Differentiated Thyroid Cancer. Thyroid 2016;26:1-133.

Copyright 2017 BMJ Publishing Group. All rights reserved. For permission to reuse any of this content visit

http://group.bmj.com/group/rights-licensing/permissions.

BMJ Case Report Fellows may re-use this article for personal use and teaching without any further permission.

Become a Fellow of BMJ Case Reports today and you can:

- Submit as many cases as you like

- Enjoy fast sympathetic peer review and rapid publication of accepted articles

- Access all the published articles

- Re-use any of the published material for personal use and teaching without further permission

For information on Institutional Fellowships contact consortiasales@bmjgroup.com

Visit casereports.bmj.com for more articles like this and to become a Fellow 